\title{
Examination of Turkish Language Teachers' Self-Efficacy Perceptions of Teaching Thinking Skills in Terms of Various Variables
}

\author{
Zeynep Cin Seker \\ Ataturk University, Kazim Karabekir Education Faculty, Erzurum, TURKEY
}

Received: 21 October 2021 - Accepted: 7 December 2021 Published Online: 27 December 2021

\begin{abstract}
The aim of this study was to examine Turkish Language teachers' self-efficacy perceptions of teaching thinking skills in terms of the variables of age, professional experience, educational status, and taking course on thinking skills. The screening model was used in the study. The current pandemic process was taken into account and the convenience sampling method was used while determining the study group. Turkish Language teachers forming the study group consisted of 109 females and 68 males. "Teachers' Self-efficacy towards teaching thinking scale" was used as the data collection tool. The data of the study were analyzed using the statistical package program. In conclusion, no significant difference was found between the Turkish Language teachers' self-efficacy perceptions of teaching thinking skills and gender. It was concluded that Turkish Language teachers' self-efficacy perceptions of teaching thinking skills differed according to professional experience. It was concluded that there was no significant difference between Turkish Language teachers' self-efficacy perceptions of teaching thinking skills and their educational status. It was concluded that there was a significant difference between Turkish Language teachers' self-efficacy perceptions of teaching thinking skills and taking course on thinking skills.
\end{abstract}

Keywords: Teaching thinking skills, Turkish Language teacher, self-efficacy.

\section{Introduction}

While thinking is an important skill that sets humans apart from other living beings and creatures, it is usually an act that we do daily without being aware of what we do. When we encounter a problem in daily life, we have to propose a solution to that problem or make a choice among existing solutions, when we read or listen to a text, we have to reach new meanings from what the author/speaker presents to us, arrange and assess our existing knowledge, reaching at a conclusion. In this context, thinking is actually an action that is at the center of our lives. In other words, thinking could be a complicated process while most of the simple decisions that we take, what we feel, do, and want in daily life emerge and are shaped as a part of our thinking ability.

Eğmir (2018) describes thinking as an action of examination people conduct towards experiences they gain during their lives. As a result of this examination, people display one of understanding, deciding, planning, problem solving, making judgment or taking action behaviors. In this sense, thinking refers to both a process and a product that must be achieved at the end of

(C) Authors. Terms and conditions of Creative Commons Attribution 4.0 International (CC BY 4.0) apply. Correspondence: Zeynep Cin Seker, Ataturk University, Kazim Karabekir Education Faculty, Erzurum, TURKEY. E-mail: zeynep.seker@atauni.edu.tr. 
this process. According to Özden (2003), thinking is the disciplined way of conceptualizing, applying, analyzing, and assessing knowledge gathered with observation, experience, perception, reasoning, and other channels. Timuçin (2004) defines thinking as the mind's act of studying and comparing concepts and ideas while accepting thinking as creating ideas by comparing concepts, deriving results from judgments by comparison and the ability to exhibit a judgment or opinion. The concept of thinking with broad scope and boundaries covers types of thinking such as creative thinking, critical thinking, problem solving, reflective thinking, and reflection (Akbıyı \& Kalkan Ay, 2014: 2). When definitions are considered, it could be argued that thinking is a process whereby individuals arrive at judgment by conducting certain logical procedures. In order for individuals to form relationships between certain concepts, situations, and events and lead comfortable lives, they need to think and create thoughts.

Although the problem of accessing knowledge seems disappeared nowadays, during which the ways to access knowledge have increased, it has brought along other needs and problems, as well. The inclusion of technological tools in our daily lives has enabled us to reach more than one knowledge on the same subject, which has also increased the speed of transportation. Reaching information about a subject that is more than necessary and the accuracy and reliability of which is uncertain has required the development of basic skills of individuals such as critical thinking, decision making, and discussion. The constantly developing and improving knowledge sources in life necessitated understanding of training, thus schools also change. Schools lost their edge of being the only source where knowledge is accessed to and learned. It is considered that in the process of training, it is important for students who experience the ways of accessing knowledge in their social life to gain and develop the thinking skills that will enable them to use the knowledge they have reached through mental processes in a functional way. According to Taşdelen (2017: 8) training of knowledge and sciences does not go beyond being an inefficient memorizing and a mere self-consuming effort unless it transforms into a thinking training and is blended with it. According to Gelen (2002: 102) although thinking is as old as humans, the efforts to systematically apply it to training are quite recent. Thinking is present at everywhere, every step of training and learning without thinking does not go beyond conditioning. In this context, it could be argued that introducing students to activities geared towards improving their thinking skills at training environment is now an obligation. Students must be raised as individuals that question and assess the world they live in, improve their language and mental skills, and apply them in various areas. The way to do this is through thinking training (Güneş, 2012: 130). The most important aim of modern education systems is bringing up individuals that think, can learn by oneself, apply what is learned and transfer by supporting this property of children (Mutlu \& Aktan, 2011: 800). Various opinions and studies towards improving thinking have been brought forward since old ages. In such studies it was aimed to make thinking skills of individuals more effective to increase their quality of life and help humans understand the nature, themselves, and their environment much better (Tok \& Sevinç, 2010: 68).

Brandt (1985) expresses thinking skills training in three main components. The first one is "teaching for thinking". Teaching of thinking means creation of teaching-learning environments by teachers and administrators that would direct students into thinking. The second one is "teaching of thinking". Teaching of thinking is teaching thinking skills in the framework of a teaching program. In teaching of thinking it is more effective to teach thinking skills by relating to a subject (from 1985, as cited in Seferoğlu and Akbiyık, 2006).

Beyer (1983) expresses those three main components are required in teaching of thinking skills. These are (as cited in French and Rhoder, 2011: 263):

1) A supportive learning environment that allows taking risks and goes beyond content;

2) Systematic, direct, integrative and developmental education; 
3) A program that allows for development of thinking skills across the curriculum and presents teacher effective knowledge.

Choosing correct approach in teaching of thinking skills is important in the context of success of teaching thinking skills. However, qualifications of teacher that is the executor of program is also an important factor in the success of the program as well as teaching of thinking skills program (Dilekli \& Tezci, 2015). Behaviors of teachers are also important for students to develop their thinking skills. Teachers must spend conscious efforts to support development of thinking. This effort must not be in a didactic teaching style explaining how students must think. In order to support development of thinking skills, teachers must introduce students to content that would motivate them to think and to duties that would encourage them to think. Thus, it is very important that teachers recognize thinking skills, notice importance of such skills, and plan how they can encourage in their classes students to think. McGregor (2007), mentions teacher behaviors who would like to improve thinking skills such as:

- Presenting open and challenging duties that allow students to think;

- Encouraging students to use knowledge they have learned in thinking processes;

- Creating cooperative groups and qualified communication environments;

- Enabling students to talk about how they perform duties towards developing their thinking skills;

- Knowing that students may have different levels of thinking skills.

Teacher qualifications, attitudes and behaviors are of great importance in the teaching of thinking skill. Considering the relationship between language and thinking, it could be said that it is important for Turkish Language teachers to have such qualities for development of language and thinking skills of students. There is a supportive and mutual relationship between language skills and thinking skill. Development of reading and listening among understanding skills, writing and speaking among narrative skills determine quality of thinking skills of individuals while development of thinking skill determines quality of language skills. According to Güneş (2012), all thoughts created in the process of thinking are transferred through language. Thus, language is not just a simple communication tool but also a tool and carrier of thinking. Yapar Gönenç and Bozkurt (2017), emphasizes that good thinking is good expressing thus, mention that justifying, moving from premise to conclusion, uniting thoughts in a certain order, deducing, proving, comparing, documenting that come to mind with thinking could be realized through language. This dual and solid relationship between language and thinking proves Turkish lessons cannot be independent of thinking skills. In this context, next to associating teaching programs of Turkish class with thinking skills; knowledge, skills, and perceptions of Turkish Language teachers regarding thinking skills and teaching of thinking skills also come forward.

In the literature, there are studies attempting to determine teachers and preservice teachers' general attitudes, perceptions, and opinions on thinking skills. When the studies on thinking skills and the teaching of thinking skills are were evaluated, there were no studies to determine the perceptions of teachers and preservice teachers on thinking skills and teaching thinking skills, their in-class practices and awareness (Akbıyık \& Kalkan Ay, 2014; Dilekli, 2015; Ekinci \& Tican, 2017; Aslan, 2017). It is noted that there are studies to determine the views, tendencies and perceptions of teachers and preservice teachers on critical thinking skills and teaching these skills (Korkmaz, 2008; Palavan, Gemalmaz \& Kurtoğlu, 2015; Koç Erdamar \& Bangir Algan, 2017). Similarly, in the literature there are studies on determining problem solving and reflective thinking skills of teachers and preservice teachers and their views, perceptions and attitudes towards teaching these skills (Demirtaş \& Dönmez, 2008; Duban \& Yanpar Yelken, 2010; 
İnel, Evrekli \& Türkmen, 2011; Kaf Hasırcı \& Sadık, 2011; Durdukoca \& Demir, 2012; Alkan \& Gözel, 2013; Bağçeci \& Kinay, 2013; Ocak \& Ĕ̆mir, 2014; Erdem \& Yazıcı̆̆ğlu, 2015; Dilekli \& Orakcı, 2019; Erol, Erol, Çalışır \& Bozan, 2019).

In the literature, there are studies on determining the opinions, attitudes and tendencies towards critical and reflective thinking skills of Turkish Language teachers and preservice teachers (Şen, 2009; Durukan \& Maden, 2010; Şahin, 2011; Çetinkaya, 2011; Bağcı \& Şahbaz, 2012; Çarkıt \& İplik, 2019), however, no studies examining the perceptions, attitudes, opinions and self-efficacy towards teaching thinking skills were found.

While the self-efficacy perception refers to people's perceptions of their own abilities, it has a determining effect on their feelings, thoughts, motives and behaviors (Ülper \& Bağcı, 2012). When self-efficacy is considered in terms of teachers, it can be expressed as a teacher's judgment about whether he/she can produce the desired results such as commitment and learning in students with his/her skills (from Tschannen-Moran \& Woolfolk Hoy, 2001 as cited in Demirtaş, Cömert \& Özer, 2011). Turkish Language teachers' knowledge, skills and experiences on thinking skills are necessary and important for the teaching of thinking skills. However, theoretical knowledge alone is not sufficient for teaching thinking skills. Thus, Turkish Language teachers should have self-efficacy for teaching thinking skills.

In this context, the aim of the study was to determine Turkish Language teachers' selfefficacy perceptions of the teaching of thinking skills. Based on the aim of the study, answers to the following questions were sought:

1) What are Turkish Language teachers' self-efficacy perceptions of teaching thinking skills according to the gender variable?

2) What are Turkish Language teachers' self-efficacy perceptions of teaching thinking skills according to their professional experience?

3) What are Turkish Language teachers' self-efficacy perceptions of teaching thinking skills according to their educational status?

4) What are Turkish Language teachers' self-efficacy perceptions of thinking skills according to taking course on thinking skills?

\section{Method}

In this section, information is given about the research model, the study group of the research, data collection and data analysis.

\subsection{Research model}

The screening model was used in this study, which aimed to examine Turkish Language teachers' self-efficacy perceptions of teaching thinking skills in terms of various variables. Screening is a research model that aims at determining a situation that existed in the past or continues to exist currently as it is. The aim of screening studies is usually to make a description by taking a picture of the current situation related to the research subject (Büyüköztürk, Kılıç-Çakmak, Akgün, Karadeniz \& Demirel, 2013; Karasar, 2020).

\subsection{Study group}

The convenience sampling was used to determine the sample of the study due to the current pandemic process. Convenience sampling is a method that prevents the waste of time. The 
researcher creates the sample starting from the most accessible respondents until he/she reaches a group of the size he/she needs (Büyüköztürk et al., 2013: 92).

Table 1. Characteristics of the study group

\begin{tabular}{|c|c|c|c|}
\hline Variables & Qualities & $\mathrm{f}$ & $\%$ \\
\hline \multirow{2}{*}{ Gender } & Female & 109 & 61.6 \\
\hline & Male & 68 & 38.4 \\
\hline \multirow{5}{*}{$\begin{array}{l}\text { Professional } \\
\text { experience }\end{array}$} & $1-5$ years & 21 & 11.9 \\
\hline & 6-10 years & 68 & 38.4 \\
\hline & 11-15 years & 40 & 22.6 \\
\hline & $16-20$ years & 34 & 19.2 \\
\hline & 21 and more & 14 & 7.9 \\
\hline \multirow{4}{*}{ Educational status } & Bachelor's degree & 119 & 67.2 \\
\hline & Doing a master's degree & 33 & 18.6 \\
\hline & Graduate of master's degree & 16 & 9.1 \\
\hline & Doing a PhD & 9 & 5.1 \\
\hline \multirow{2}{*}{$\begin{array}{l}\text { Taking course on } \\
\text { thinking skills }\end{array}$} & Yes & 109 & 61.6 \\
\hline & No & 68 & 38.4 \\
\hline
\end{tabular}

\subsection{Data collection tools}

The "Personal Information Form" (PIF) prepared by the researcher and the "Teachers' Self-efficacy towards teaching thinking scale" developed by Dilekli and Tezci (2015) were used to determine the self-efficacy perceptions of teaching thinking skills of Turkish Language teachers who constituted the sample of the study.

The personal information form included questions to determine Turkish Language teachers' gender, professional experience, educational status, and taking courses on thinking skills during their education (undergraduate, master's degree, doctorate).

The "Teachers' Self-efficacy towards teaching thinking scale" is a 5-point Likert scale and consists of 20 items. In the scale, the statements of "strongly agree" (5) and "agree" (4) were used for positive items, and the statements of "strongly disagree" (1) and "disagree" (2) were used for negative items. The statement of "undecided" was used for the items without a positive or negative opinion. The scale consists of "Academic competence", "Application" and "Design" subdimensions. Dilek and Tezci (2015) determined the Alpha reliability coefficient of the overall scale as .95. In this study, the Alpha reliability coefficient of the scale was determined as .96.

\subsection{Data collection and analysis}

In the data collection process of the study, the scale was not delivered to the participants face to face by considering the current pandemic process. The information form, the data collection tool of the study, the scale, and the measurement tool with brief information about the study and the consent for participation in the study were transferred to the Google Forms environment. Participants were informed that participation in the study was on a voluntary basis. The link created via Google Forms was shared with teacher groups in the virtual environment (such as Facebook, Whatsapp, Instagram). The data collection process was terminated when it was observed that participation in the questionnaire was completed. The data collection process took 7 days.

The data of the study were analyzed using the statistical package program. In the analysis process, whether the data obtained from the scale were normally distributed was first checked. The condition of the data meeting the normality assumptions was decided by evaluating 
the Kolmogorov Smirnov test. Parametric tests were used for the data with normal distribution, and nonparametric tests were used for the data without normal distribution. In the analysis of the data with normal distribution, the T-test for Independent Samples was used in cases with two samples, and for the data without normal distribution, Mann Whitney U test was used in cases with two independent samples, and the data were analyzed by Kruskal Wallis Test in cases with more than two independent samples.

\section{Results}

This section includes the results on whether there was a significant difference between Turkish Language teachers' self-efficacy perceptions of teaching thinking skills according to the variables of gender, professional experience, educational status, and taking courses on thinking skills.

The results of the Mann Whitney U Test, in which Turkish Language teachers' selfefficacy perceptions of teaching thinking skills were examined according to gender, are presented in Table 2.

Table 2. Mann Whitney U test results of Turkish language teachers' self-efficacy perceptions of teaching thinking skills according to gender variable

\begin{tabular}{lccccc}
\hline Gender & $\mathrm{n}$ & $\bar{X}$ & $\mathrm{SD}$ & $\mathrm{U}$ & $\mathrm{p}$ \\
\hline Female & 109 & 87.54 & 9541.50 & 3546.500 & .630 \\
Male & 68 & 91.35 & 6211.50 & \\
\hline
\end{tabular}

According to Table 2, while the arithmetic mean of the score indicating female Turkish Language teachers' self-efficacy perceptions of teaching thinking skills was 87.54, it was 91.35 among male Turkish Language teachers. When the mean scores of male and female Turkish Language teachers were evaluated, although it was observed that the mean score of male teachers was higher, this difference was not statistically significant. Therefore, there was no significant difference between Turkish Language teachers' self-efficacy perceptions of teaching thinking skills and gender $(\mathrm{U}=3546.500, \mathrm{p}<.05)$. In this case, it can be said that gender had no effect on Turkish Language teachers' self-efficacy perceptions of teaching thinking skills.

The results of the Kruskal Wallis test, in which Turkish Language teachers' selfefficacy perceptions of teaching thinking skills were examined according to professional experience, are presented in Table 3 .

Table 3. Kruskal Wallis test results of Turkish language teachers' self-efficacy perceptions of teaching thinking skills according to professional experience variable

\begin{tabular}{lccccc}
\hline $\begin{array}{l}\text { Professional } \\
\text { experience }\end{array}$ & $\mathrm{n}$ & $\begin{array}{l}\text { Mean } \\
\text { Rank }\end{array}$ & $\mathrm{SD}$ & $\mathrm{X}^{2}$ & $\mathrm{p}$ \\
\hline 1-5 years & 20 & 92.43 & 4 & 14.515 & .006 \\
6-10 years & 67 & 80.07 & & & \\
11-15 years & 39 & 111.13 & & & \\
16-20 years & 38 & 73.79 & & & \\
21 years & 13 & 107.81 & & & \\
and more & & & & & \\
\hline
\end{tabular}

According to Table 3, Turkish Language teachers' self-efficacy perceptions of teaching thinking skills differed according to their professional experience $(\mathrm{p}<.05)$. However, it can be said that this difference was not related to the duration of the experience. While the mean score of teachers with 1-5 years of experience was 92.43, the mean score of teachers with 6-10 years of experience was 80.07, the mean score of teachers with 11-15 years of experience was 111.73, the mean score of teachers with 16-20 years of experience was 73.79, and the mean score of teachers 
with 21 years/more years of experience was 107.81. Based on the mean scores, it can be said that teachers with less and more experience had higher self-efficacy perceptions.

The results of the Kruskal Wallis Test, in which Turkish Language teachers' selfefficacy perceptions of teaching thinking skills were examined according to their educational status, are presented in Table 4.

Table 4. Kruskal Wallis test results of Turkish Language teachers' self-efficacy perceptions of teaching thinking skills according to the graduation status variable

\begin{tabular}{cccccc}
\hline $\begin{array}{c}\text { Educational } \\
\text { status }\end{array}$ & $\mathrm{n}$ & $\begin{array}{c}\text { Mean } \\
\text { Rank }\end{array}$ & SD & $X^{2}$ & $\mathrm{p}$ \\
\hline $\begin{array}{c}\text { Bachelor's } \\
\text { degree }\end{array}$ & 118 & 86.70 & 3 & 2.179 & .536 \\
$\begin{array}{c}\text { Doing a } \\
\text { master's } \\
\text { degree }\end{array}$ & 33 & 88.97 & & & \\
$\begin{array}{c}\text { Graduate of } \\
\text { master's } \\
\text { degree }\end{array}$ & 16 & 92.16 & & & \\
Doing a PhD & 10 & 111.20 & & & \\
\hline
\end{tabular}

According to Table 4, it was observed that there was no significant difference between Turkish Language teachers' self-efficacy perceptions of teaching thinking skills and their graduation status ( $\mathrm{p}>.05$ ). Based on this result, it can be said that the graduation status of Turkish Language teachers did not affect their self-efficacy perceptions of teaching thinking skills. Although there was no significant difference between Turkish Language teachers' self-efficacy perceptions of teaching thinking skills and their graduation status, Turkish Language teachers doing a PhD had a mean score of 111.20, those with master's degree had a mean score of 92.16, those doing a master's degree had a mean score of 88.97, and those with bachelor's degree had a mean score of 86.70. In this context, although there was no statistically significant difference between Turkish Language teachers' educational status and their self-efficacy perceptions of teaching thinking skills, it can be stated that mean score of self-efficacy perceptions of teaching thinking skills increased as the level of education increased.

The results of T-test for Independent Samples, in which Turkish Language teachers' self-efficacy perceptions of teaching thinking skills were examined according to taking course on thinking skills, are presented in Table 5 .

Table 5. T-test for Independent Samples results of Turkish Language teachers' self-efficacy perceptions of teaching thinking skills according to the variable of taking course on thinking skills

\begin{tabular}{ccccccc}
\hline & Groups & $\mathrm{n}$ & $\bar{X}$ & $\mathrm{SD}$ & $\mathrm{T}$ & $\mathrm{p}$ \\
\hline \multirow{2}{*}{ Overall } & Yes & 109 & 83.08 & 11.83 & \multirow{2}{*}{3.317} & \multirow{2}{*}{.001} \\
\cline { 2 - 6 } Average & No & 68 & 76.67 & 13.50 & & \\
\hline
\end{tabular}

When Table 5 was examined, it was observed that there was a significant difference between Turkish Language teachers' self-efficacy perceptions of teaching thinking skills and taking course on thinking skills $(\mathrm{t}(175)=3.317, \mathrm{p}<.05)$. While the mean score of the Turkish Language teachers who took courses on thinking skills was 83.08, the mean score of the Turkish Language teachers who did not take it was 76.67. It was determined that this difference between the mean scores was due to the significant difference in favor of those who took courses on thinking skills in Turkish Language teachers' self-efficacy perceptions of teaching thinking skills. Therefore, it can be said that Turkish Language teachers taking courses on thinking skills positively affected their self-efficacy perceptions of teaching thinking skills. 


\section{Discussion and conclusion}

In this study, Turkish Language teachers' self-efficacy perceptions of teaching thinking skills were examined according to gender, professional experience, educational status, and taking courses on thinking skills. This section includes the results of the study, and the discussion of the results together with the relevant studies.

It was determined that the mean score of Turkish Language teachers' self-efficacy perceptions of teaching thinking skills was 91.35 for male teachers and 87.54 for female teachers. Although the mean score of male Turkish Language teachers was higher compared to female teachers, it was concluded that this difference did not constitute a statistically significant difference. No significant difference was found between the Turkish Language teachers' selfefficacy perceptions of teaching thinking skills and gender. No study on Turkish Language teachers' self-efficacy perceptions of teaching thinking skills was found in the literature, however, it was observed that there were studies examining Turkish Language teachers' self-efficacy. Saracaloğlu, Karasakaloğlu and Evin Gencel (2010) and Şahin (2019) concluded that Turkish Language teachers' self-efficacy did not differ according to gender.

In the studies examining classroom teachers' self-efficacy perceptions of teaching thinking skills, it was also concluded that there was no significant difference between classroom teachers' self-efficacy perceptions of teaching thinking skills and gender (Aslan, 2017; Dilekli, 2015). According to Ekinci and Tican (2017), there was no significant relationship between classroom teachers' in-class practices for thinking skills and gender. While Dinçer Göbel (2013) found that there was no significant relationship between teaching critical thinking skills of classroom teachers and gender, Gelen (2002) found that there was no significant relationship between their abilities to gain thinking skills and gender.

It was observed that similar results were obtained in the studies examining the selfefficacy perceptions of teachers and preservice teachers. While Aslan and Kalkan (2018) reported that there was no significant relationship between teachers' self-efficacy perceptions and gender, Baykara (2011) reported that there was no significant relationship between preservice teachers' self-efficacy perceptions and gender. Ülper and Bağcl (2012) determined that professional selfefficacy perception scores of preservice Turkish Language teachers did not make a significant difference according to gender, however, there was a significant difference in favor of female students in the sub-dimension of private content knowledge. It was also observed that different results were achieved in few studies examining self-efficacy perceptions of teachers and preservice teachers compared to this study. Selçuk (2013) determined that there was a significant difference in favor of female teachers between Turkish Language teachers' special field competencies and gender. Çapri and Çelikkaleli (2008) concluded that the self-efficacy perceptions of preservice teachers made a significant difference in favor of female preservice teachers. Yeşilyurt (2013) and Demirtaş, Cömert and Özer (2011) found that male preservice teachers had higher self-efficacy perceptions compared to female preservice teachers. In their study, Coşkun, Gelen and Öztürk (2009) examined preservice Turkish Language teachers' self-efficacy perceptions of instructional planning, implementation and evaluation, they found that male students' mean perception of efficacy was higher compared to female preservice teachers, however, this result did not lead to a statistically significant difference.

It was concluded that Turkish Language teachers' self-efficacy perceptions of teaching thinking skills differed according to professional experience. While the mean score of teachers with 1-5 years of experience was 92.43, the mean score of teachers with 6-10 years of experience was 80.07, the mean score of teachers with 11-15 years of experience was 111.73, the mean score of teachers with 16-20 years of experience was 73.79, and the mean score of teachers with 21 years/more years of experience was 107.81. When the mean scores were examined, it was observed that Turkish Language teachers with the highest self-efficacy perceptions of teaching thinking 
skills were the teachers with 11-15 years of experience, and those with the lowest self-efficacy perceptions were the teachers with 16-20 years of experience. Teachers' self-efficacy perceptions of teaching thinking skills are expected to increase as professional experience increases. However, it can be said that the results of the study did not meet this expectation. It was concluded that teachers' self-efficacy perceptions of teaching thinking skills were not directly associated with having less or more professional experience. In this case, it can be stated that the individual efforts and wishes of teachers are important. Aslan (2017) concluded that there was no significant difference between classroom teachers' self-efficacy perceptions of teaching thinking skills and their professional experiences. Ekinci and Tican (2017) indicated that there was no significant difference between classroom teachers' practices for thinking skills and their professional experience, however, the mean of teachers with 11-20 years of professional experience was higher. Dilekli (2015) determined that there was a significant difference between teaching thinking skills and professional seniority and stated that professionally experienced teachers included more inclass activities for teaching thinking skills, and therefore, teachers with more professional experience also had higher self-efficacy levels for teaching thinking skills. Selçuk (2013) reported that there was no significant difference between the critical thinking skills of Turkish Language teachers and their professional experience, however, the mean score increased as the duration of experience increased.

Korkmaz (2008) examined teachers' critical thinking dispositions and levels and concluded that teachers' professional experience did not affect their critical thinking dispositions and levels. In their study, Demirtaş and Dönmez (2008) examined secondary school teachers' perceptions of problem-solving skills and determined that their perceptions of problem-solving skills decreased as their professional experience increased. In their study, Durdukoca and Demir (2012) attempted to determine the reflective thinking levels of primary school Turkish Language and Mathematics teachers and found that there was no significant relationship between teachers' reflective thinking levels and their professional experiences. Saracaloğlu et al. (2010) examined self-efficacy perceptions of Turkish Language teachers and the professional experiences of Turkish Language teachers did not affect their self-efficacy perceptions. Aslan and Kalkan (2018) found that there was a significant difference between teachers' self-efficacy perceptions and their professional experience in favor of teachers with more professional experience. Dinçer and Göbel (2013) concluded that there was a significant difference between classroom teachers' competencies of critical thinking teaching and their professional experience in favor of teachers with more experience.

It was concluded that there was no significant difference between Turkish Language teachers' self-efficacy perceptions of teaching thinking skills and their educational status. However, it was observed that the mean scores of Turkish Language teachers increased as their educational status increased. While the mean score of Turkish Language teachers with bachelor's degree was 86.70 , the mean score of those doing a master's degree was 88.97, the mean score of those with master's degree was 92.16, and the mean score of those doing a PhD was 111.20. Although it was determined that there was no statistically significant difference between educational status and self-efficacy perceptions of teaching thinking skills, it can be stated that the mean scores increased as the educational status increased. In most of the studies in the literature, it was concluded that there was a significant difference between the teaching of thinking skills and the educational status. While Aslan (2017) determined that there was no significant difference between classroom teachers' self-efficacy perceptions of teaching thinking skills and their educational status, Ekinci and Tican (2017) determined that there was no significant difference between classroom teachers' in-class practices for thinking skills and their educational status. Bağçeci and Kinay (2013) determined that there was no significant difference between teachers' problem-solving skills and their educational status. 
It was concluded that there was a significant difference between Turkish Language teachers' self-efficacy perceptions of teaching thinking skills and taking course on thinking skills. While the mean score of Turkish Language teachers who took courses on thinking skills was 83.08, the mean score of Turkish Language teachers who did not take courses on thinking skills was 76.67. Aslan (2017) also determined that the self-efficacy perceptions of teaching thinking skills of classroom teachers who took courses on thinking skills made a significant difference. In this context, it can be said that teachers' taking courses on thinking skills and teaching these skills in their undergraduate or graduate education have an effect on their self-efficacy perceptions of teaching thinking skills. Dinçer Göbel (2013) concluded that the classroom teachers' taking courses on critical thinking skills did not make a significant difference in general, however, there was a significant difference in favor of those who took courses on critical thinking skills in the teacher qualifications sub-dimension.

\section{Recommendations}

1. Although the teaching of thinking skills generally concerns all teaching fields, it is an issue that Turkish Language teachers should especially focus on, when the relationship between language and thought is considered. Therefore, Turkish Language teachers should perform studies for the acquisition of thinking skills and should improve themselves in this regard.

2. Teachers should be provided to encounter courses on thinking skills or the teaching of thinking skills during the undergraduate period, which is the pre-service education period, and during the postgraduate education period.

3. Turkish Language teachers can be provided with in-service trainings on how to improve their thinking skills in Turkish Language courses.

\section{Ethic Committee Approval}

Ethics Committee Approval was given to this study with the decision No. 11 at the meeting No. 06 held on 18 June 2021 by Atatürk University Educational Sciences Unit Ethics Committee.

\section{Acknowledgements}

This research did not receive any specific grant from funding agencies in the public commercial, or not-for-profit sectors.

The author declares no competing interests.

\section{References}

Akbıyık, C., \& Kalkan Ay, G. (2014). Okul öncesi yönetici ve öğretmenlerin düşünme becerilerinin öğretimine yönelik algıları: bir durum çalışması. Hacettepe Üniversitesi Eğitim Fakültesi Dergisi, 29(1), 1-18. https://dergipark.org.tr/tr/download/article-file/87074.

Alkan, V., \& Gözel, E. (2013). Sınıf öğretmeni adaylarının yansıtıcı düşünme becerilerine ilişkin görüşleri. e-Journal of New World Sciences Academy, 8(1), 1-12. https://dergipark.org.tr/tr/download/article-file/185405. 
Aslan, M., \& Kalkan H. (2018). Öğretmenlerin özyeterlik algılarının analizi. Bingöl Üniversitesi Sosyal Bilimler Enstitüsü Dergisi, 8(16), 477-493. http://dx.doi.org/10.29029/busbed.434926

Aslan, S. (2017). Sınıf öğretmenlerinin düşünme becerisi öğretimine yönelik özyeterlik algılarının çeşitli değişkenler açısından incelenmesi. Pamukkale Üniversitesi Ĕ̆itim Fakültesi Dergisi, 41, 6173. http://dx.doi.org/10.9779/PUJE675

Bağcı, H., \& Şahbaz N. K. (2012). Türkçe öğretmeni adaylarının eleştirel düşünme beceriler üzerine bir değerlendirme. Mersin Üniversitesi Eğitim Fakültesi Dergisi, 8(1), 1-12. https://dergipark.org.tr/tr/download/article-file/160811.

Bağçeci, B., \& Kinay, İ. (2013). Öğretmenlerin problem çözme becerilerinin bazı değişkenlere göre incelenmesi. Electronic Journal of Social Sciences, 12(44), 335-347.

Baykara, K. (2011). Öğretmen adaylarının bilișötesi öğrenme stratejileri ile öğretmen yeterlik algıları üzerine bir çalışma. Hacettepe Üniversitesi Eğitim Fakültesi Dergisi, 40, 80-92. https://dergipark.org.tr/en/download/article-file/87351.

Büyüköztürk, Ş., Kılıç Çakmak, E., Akgün, Ö. E., Karadeniz, Ş., \& Demirel, F. (2015). Bilimsel araştırma yöntemleri. (19. Basım). Ankara: Pegem Akademi Yayınları.

Coşkun, E., Gelen, İ., \& Öztürk, E. P. (2009). Türkçe öğretmen adaylarının öğretimi planlama, uygulama ve değerlendirme yeterlik algıları. Mustafa Kemal Üniversitesi Sosyal Bilimler Enstitüsü Dergisi, 6(12), 140-163.

Çapri, B., \& Çelikkaleli, Ö. (2008). Öğretmen adaylarının öğretmenliğe ilişkin tutum ve mesleki yeterlik inançlarının cinsiyet, program ve fakültelerine göre incelenmesi. İnönü Üniversitesi Ĕ̆itim Fakültesi Dergisi, 9(15), 33-53. https://dergipark.org.tr/tr/download/article-file/92333.

Çarkıt, C., \& İplik, Y. (2021). Ortaokul Türkçe derslerinde yansıtıcı düşünme becerisinin geliştirilmesine yönelik öğretmenlerin görüş ve uygulamaları. Gazi Üniversitesi Gazi Ĕ̆itim Fakültesi Dergisi, 41(1), 497-524. http://www.gefad.gazi.edu.tr/tr/pub/issue/62024/831314.

Çetinkaya, Z. (2011). Türkçe öğretmen adaylarının eleştirel düşünmeye ilişkin görüşlerinin belirlenmesi. Ahi Evran Üniversitesi Ë̆itim Fakültesi Dergisi, 12(3), 93-108. https://dergipark.org.tr/tr/download/article-file/1492276.

Demirtaş, H., \& Dönmez, B. (2008). Ortaöğretimde görev yapan öğretmenlerin problem çözme becerilerine ilişkin algıları. İnönü Üniversitesi Eğitim Fakültesi Dergisi, 9(16), 177-198. https://dergipark.org.tr/tr/download/article-file/92319.

Demirtaş, H., Cömert, M., \& Özer, N. (2011). Öğretmen adaylarının öz-yeterlik inançları ve öğretmenlik mesleğine ilişkin tutumları. Eğitim ve Bilim, 36(159), 96-111. http://egitimvebilim.ted.org.tr/index.php/EB/article/view/278/241.

Dilekli, Y. (2015). Öğretmenlerin düşünmeyi öğretmeye yönelik yaptıkları sınıfiçi uygulamalar, özyeterlik düzeyleri ve öğretim stilleri arasındaki ilişki [Doctoral dissertation, Mugla Sitki Kocman University].

Dilekli, Y., \& Tezci, E. (2015). Öğretmenlerin düşünme becerisi öğretimine yönelik özyeterlik alglları ölçeği geçerlik ve güvenirlik çalışması. International Journal of Social Science, 38, 135-153. http://dx.doi.org/10.9761/JASSS3056

Dilekli, Y., \&Orakcı, Ş. (2019). Öğretmenlerin yansıtıcı düşünme becerilerinin çeşitli değişkenlere göre incelenmesi. OPUS, 11(18), 1517-1539. http://dx.doi.org/10.26466/opus.550187

Dinçer Göbel, Ş. (2013). Sinıf öğretmenlerinin eleştirel düşünme becerisi öğretimi yeterlilikleri ve uygulamalart [Master's thesis, Sakarya University].

Duban, N., \& Yanpar Yelken, T. (2010). Öğretmen adaylarının yansıtıcı düşünme eğilimleri ve yansıtıcı öğretmen özellikleriyle ilgili görüşleri. Çukurova Üniversitesi Sosyal Bilimler Enstitüsü Dergisi, 19(2), 343-360. https://dergipark.org.tr/tr/download/article-file/50607. 
Durukan, E., \& Maden, S. (2010). Türkçe öğretmeni adaylarının eleştirel düşünme eğilimleri üzerine bir araştırma. Dumlupinar Üniversitesi Sosyal Bilimler Dergisi, 28, 25-34. https://dergipark.org.tr/tr/download/article-file/55647.

Eğmir, E. (2018). Eleştirel düşünme becerisi öğretimi: ortaokul öğrencileri için bir program tasarısı. Ankara: Pegem Akademi Yayınları.

Ekinci, N., \& Tican, C. (2017). Sinıf öğretmenlerin epistemolojik inançları ve düşünme becerilerinin öğretimine yönelik sınıf içi uygulamaları. İnsan ve Toplum Bilimleri Araştırmaları Dergisi, 6(3), 1747-1773. http://www.itobiad.com/tr/download/article-file/337634.

Erdem, A. R., \& Yazıcıŏ̆lu, A. (2015). Öğretmen adaylarının problem çözme becerileri ile eleştirel düşünme becerileri arasındaki ilişki. OPUS, 5(9), 37-41. https://dergipark.org.tr/tr/download/articlefile/210719.

Erol, M., Erol, A., Çalışır, S., \& Bozan, M. (2019). Öğretmenlerinin yansıtıcı düşünme eğilimleri ile yaratıcı düşünme düzeyleri arasındaki ilişkinin incelenmesi. Temel Eğitim Dergisi, 1(2), 20-29. https://dergipark.org.tr/tr/download/article-file/701412.

Fırat Durdukoca, Ş., \& Demir, M. (2012). İlköğretim öğretmenlerin bazı değişkenlere göre yansıtıcı düşünme düzeyleri ve düşüncelerindeki öğretmen niteliklerinin yansıtıcı öğretmen niteliklerine uygunluğu. Mustafa Kemal Üniversitesi Sosyal Bilimler Enstitüsü Dergisi, 9(20), 357-374. https://dergipark.org.tr/tr/download/article-file/183091.

French, J. N., \& Rhoder, C. (2011). Teaching thinking skills. Routledge.

Gelen, D. (2002). Sınıf öğretmenlerinin sosyal bilgiler dersinde düşünme becerilerini kazandırma yeterliklerinin değerlendirilmesi. Çukurova Üniversitesi Sosyal Bilimler Enstitüsü Dergisi, 1O(10), 100-119. https://dergipark.org.tr/tr/download/article-file/50111.

Güneş, F. (2012). Öğrencilerin düşünme becerilerini geliştirme. TÜBAR, 32, 127-146. https://dergipark.org.tr/tr/download/article-file/157123.

İnel, D., Evrekli, E., \& Türkmen, L. (2011). Sınıf öğretmeni adaylarının problem çözme becerilerinin araştırılması. Pamukkale Üniversitesi Eğitim Fakültesi Dergisi, 11(1), 167-178. https://dergipark.org.tr/tr/download/article-file/114604.

Kaf Hasırcı, Ö., \& Sadık, Ö. (2011). Sınıf öğretmenlerinin yansıtıcı düşünme eğilimlerinin incelenmesi. Çukurova Üniversitesi Sosyal Bilimler Enstitüsü Dergisi, 2O(2), 195-210. https://dergipark.org.tr/tr/download/article-file/50687.

Karasar, N. (2020). Bilimsel araştırma yöntemi. Ankara: Nobel Yayıncllı.

Koç Erdamar, G., \& Bangir Alpan, G. (2017). Eleştirel düşünme algısı: lise öğretmenleri üzerine bir araştırma. Elektronik Sosyal Bilimler Dergisi, 16(62), 787-800. https://doi.org/10.17755/esosder.305631

Korkmaz, Ö. (2008). Öğretmenlerin eleştirel düşünme eğilim ve düzeyleri. Ahi Evran Üniversitesi Kirşehir Ĕ̆itim Fakültesi Dergisi, 1O(1), 1-13. https://dergipark.org.tr/tr/download/articlefile/1494903.

McGregor, D. (2007). Developing thinking; developing learning. Open University Press.

Mutlu, E., \& Aktan, E. (2011). Okul öncesi öğretmenlerinin düşünme eğitimi ile ilgili tutumlarının incelenmesi. Türk Eğitim Bilimleri Dergisi, 9(4), 799-830. https://dergipark.org.tr/tr/download/article-file/256200.

Ocak, G., \& Eğmir, E. (2014). Öğretmen adaylarının problem çözme becerilerinin çeşitli değişkenler açısından incelenmesi. Asya Öğretim Dergisi, $2(1), \quad 27-45$. https://dergipark.org.tr/tr/download/article-file/17639.

Özden, Y. (2003). Öğrenme ve öğretme. Ankara: Pegem Akademi Yayınları.

Palavan, Ö., Gemalmaz, N., \& Kurtoğlu, D. (2015). Sınıf öğretmenlerinin eleştirel düşünme becerisine ve eleştirel düşünme becerisinin geliştirilmesine yönelik görüşleri. Mustafa Kemal Üniversitesi 
Sosyal Bilimler Enstitüsü Dergisi, $\quad 12(30), \quad$ 26-49. https://dergipark.org.tr/tr/download/article-file/183398.

Saracaloğlu, A. S., Karasakaloğlu, N., \& Gencel, İ, E. (2010). Türkçe öğretmenlerinin özyeterlik düzeylerinin çeşitli değişkenlere göre incelenmesi. Elektronik Sosyal Bilimler Dergisi, 33, 265-283. https://dergipark.org.tr/tr/download/article-file/70212.

Seferoğlu, S. S., \& Akbıyık, C. (2006). Eleştirel düşünme ve öğretimi. Hacettepe Üniversitesi Eğitim Fakültesi Dergisi, 3o, 193-200. https://yunus.hacettepe.edu.tr/ sadi/yayin/SeferogluAkbiyik EFDergi-2006 Eles.Dusun.pdf.

Selçuk, B. (2013). Türkçe öğretmenlerinin eleştirel düşünme eğilimleri ve özel alan yeterlilik düzeyleri arasındaki ilişkinin incelenmesi (Muğla ili örneği) [Master's thesis, Mugla Sitki Kocman University].

Şahin, A. (2011). Türkçe öğretmeni adaylarının yansıtıcı düşünme eğilimlerinin çeşitli değişkenlere göre değerlendirilmesi. Elektronik Sosyal Bilimler Dergisi, 1O(37), 108-119. https://dergipark.org.tr/tr/download/article-file/70293.

Şahin, B. (2019). Türkçe öğretmen adayları ve Türkçe öğretmenlerinin öz yeterlik algıları [Master's thesis, Kafkas University].

Şen, Ü. (2009). Türkçe öğretmeni adaylarının eleştirel düşünme tutumlarının çeşitli değişkenler açısından değerlendirilmesi. Zeitschrift für die Welt der Türken/Journal of World of Turks, 1(2), 69-89.

Timuçin, A. (2004). Felsefe sözlüğü. İstanbul: Bulut Yayınları.

Taşdelen, V. (2017). Çocuk kültürü bağlamında çocuklarla felsefe. Çocuk ve Medeniyet, 2, 7-17.

Tok, S., \& Sevinç, M. (2010). Düşünme becerileri eğitiminin eleştirel düşünme ve problem çözme becerilerine etkisi. Pamukkale Üniversitesi Eğitim Fakültesi Dergisi, 27, 67-82. https://dergipark.org.tr/tr/download/article-file/114637.

Ülper, H., \& Bağcı, H. (2012). Türkçe öğretmeni adaylarının öğretmenlik mesleğine dönük öz yeterlik algıları. Turkish Studies, 7(2), 1115-1135. http://dx.doi.org/10.7827/TurkishStudies.3039.

Yapar Gönenç. A., \& Bozkurt, G. (2017). Dil temelinde felsefe ve medya. İstanbul: Der Yayınları.

Yeşilyurt, E. (2013). Öğretmen adaylarının öğretmen öz-yeterlik algıları. Elektronik Sosyal Bilimler Dergisi, 12(45), 88-104. 
Z. Cin Seker - Examination of Turkish Language Teachers' Self-Efficacy Perceptions of...

C O A $\mathrm{s}$ 